\title{
A STUDY OF THE ANTICOCCIDIAL EFFECTS OF CLOPIDOL AND GARLIC POWDER ON EIMERIA-INFECTED BROILERS
}

\author{
EL DAKROURY, M.F.; REDA, S. FADLY and BAZ, G.M. \\ Animal Health Research Institute
}

Received: 30 September 2016; $\quad$ Accepted: 17 October 2016

\begin{abstract}
This work was carried out to compare between the anticoccidial efficacy of clopidol and garlic powder. Three groups of one day old Hubbard chicks each of 30 birds were used in this study. The $1^{\text {st }}$ group received only basal ration (control). The second group received clopidol $125 \mathrm{mg} / \mathrm{kg} \mathrm{B}$.W. The third group received garlic powder 5 gram $/ \mathrm{kg} \mathrm{B.W}$. Birds in all groups were infected with a field stain of Eimeria spp. (50.000 oocysts / bird) at 21 days of age. Mortality rate and clinical signs of coccidiosis were recorded. Also, oocyst count/gm faeces, body weight gain and feed conversion were measured at $7^{\text {th }}, 14^{\text {th }}$ and $21^{\text {th }}$ day after challenge. Five birds in each group were killed one week post infection and lesion score was determined. Blood samples were collected from birds of each group at the end of experiment for detection of serum levels of AST, ALT, creatinine and uric acid. The obtained data demonstrated that administration of clopidol or garlic powder evoked a significant decrease in mortality rate, oocyst count/gm droppings, lesion score and clinical signs of coccidiosis, compared with infected non treated group. Also, adding of clopidol or garlic powder improved the performance of the birds. The serum level of AST, ALT, createnine and uric acid was decreased by both treatment. It was noticed that addition of garlic powder induce more prominent effects than clopidol in improving the feed conversion (at 21 day post infection) and serum creatinin level and decreasing the mortality rate. On the other hand, clopidol treated group had a lower oocysts count/gm droppings $\left(1^{\text {st }}\right.$ and $2^{\text {nd }}$ week post infection) compared with other groups.
\end{abstract}

Key words: Anticoccidial, Clopidol, Garlic Powder, Eimeria-Infected, Broilers.

\section{INTRODUCTION}

Coccidiosis remains one of the most expensive and common diseases of poultry in spite of advances in chemotherapy, management, nutrition and genetics. (Cox, 1998 and Ernik and Bedrnik, 2001). It leads to the extensive destruction of the intestinal epithelium which results in reduced food efficiency and body weight gain, as well as a temporary reduction in egg production (Min et al., 2004 and Dalloul and Lillehoj 2005). This has a considerable economic loss at the level of poultry industry.

Clopidol is one of the anticoccidial drugs acts by inhibiting coccidial respiration by interfering with cytochrome-mediated electron transport in the parasites mitochondria (Fry and Williams, 1984; Long 1993; Adam, 2001 and Walter, 2008). This was confirmed by Sevcik and Danek (1972) who found that, the number of oocysts excreted in the faeces of birds treated with clopidol was much lower than in

Corresponding author: Dr. REDA, S. FADLY

E-mail address: dr_redafadly@yahoo.com

Present address: Animal Health Research Institute the control one. Moreover the authors mentioned that, the higher the dosage of clopidol, the lower oocysts count. This was also reported by Bahadoran et al. (2013).

There are numerous reports indicating the efficacy of garlic in the prevention and treatment of a variety of diseases and for validating its traditional uses. For instance, garlic has been described to exhibit antimicrobial activity (Chowdhury et al., 1991; Yoshida et al., 1998; Fleischauer et al., 2000), antitumor activity (Sundaram and Milner, 1996; Karasaki et al., 2001), as well as antithrombotic, antiarthritic, hypolipidemic, and hypoglycemic activities (Duraka et al., 2002; Kumar et al., 2003). Moreover, garlic has been reported to be effective against diverse parasites such as Amoeba (Peyghan et al., 2008), Leishmania (Ghazanfari et al., 2006), Trypanosoma (Nok et al., 1996) Cryptosporidium (Wahba, 2003) and coccidiosis (Worku et al. 2009; Dkhil et al., 2011 and Pourali, et al. 2014).

At the present study, the anticoccidial effects of clopidol and garlic were evaluated in broilers. 


\section{MATERIALS AND METHODS}

\section{Drug}

Clopidol was used in the form of a pharmaceutical preparation Lopidolmix ${ }^{\circledR}$ (registered by Atco Pharma). Each $1 \mathrm{~kg}$ contains clopidol $250 \mathrm{gm}$.

\section{Preparation of garlic powder}

Garlic bulbs were purchased from a local source. The bulbs were chopped into tiny cuts, sun dried, winnowed to remove the husk and then ground into fine powder.

\section{Chickens}

Ninety Chickens, one day old Hubbard chicks were used in the present study. All chicks were reared in separate cages and were fed on a balanced ration. Free access of Feed and water was also allowed.

\section{Grouping and experimental design:}

The chicks were divided into three equal groups, each of 30 chick. The first group was kept non infected and served as a control, the second group was treated with $125 \mathrm{ppm}$ of clopidol, the third group was treated with 5 gram $/ \mathrm{kg} \mathrm{B.W}$ of garlic powder. Isolation of field Eimeria strain, sporulation and propagation of the oocysts was carried out according to the method described by Saif (2003). At $21^{\text {th }}$ day of age, about 50,000 oocysts were given orally to each birds in all experimental groups Oocyst count/gm faeces and faecal score examination were performed at $7^{\text {th }}, 14^{\text {th }}$ and $21^{\text {th }}$ day after challenge.

\section{Evaluation of the anticoccidial efficacy}

\section{Oocyst count:}

Faecal samples were collected at $7^{\text {th }}, 14^{\text {th }}$ and $21^{\text {th }}$ day after challenge for oocyst count and faecal score examination. The oocyst count was carried out according to the method described by Abd ElRahman et al. (1982).

\section{Post mortem and lesion score:}

The method described by Elbahy et al. (2006) was used. Five birds were killed one week post infection and a scoring system (according to the severity of infection) was adopted between 0 and ++++ .
Final body weight and feed conversion rate:

The feed conversion rates were calculated according to the following equation:

feed conversion rates $=$ consumed feed (grams)/ body weight gain $($ grams $) \times 100$

\section{The biochemical analysis:}

Blood samples were collected from birds of each group at the end of the experiment. Serum AST, and ALT were measured according to Reitman and Frankel (1957), Createnine by Seeling and Wust (1969) and uric acid (Baraham and Trinder, 1972).

\section{Mortality rate:}

Number of dead birds were also recorded throughout the experiment to calculate the morality rate (number of dead birds / total number of birds in each group).

\section{Clinical signs:}

After infection, chickens were kept under observation for recording the intensity of clinical signs of coccidiosis as diarrhea, bloody faeces, stop feeding and depression (Brandcr et al., 1991).

\section{Statistical analysis:}

Data were statistically analyzed using one-way analysis of variance and Duncan's multiple range test was used for comparison between means (SAS, 1998).

\section{RESULTS}

The obtained data concerning the effect of clopidol and garlic powder on the chickens infected with Eimeria spp. revealed that administration of clopidol or garlic powder evoked a significant decrease in oocyst count/gm droppings, lesion score, clinical signs of coccidiosis and mortality rate compared with infected non treated group. Also, adding of clopidol or garlic powder improved the performance of the birds. The activity of serum AST, ALT, createnine and uric acid was decreased by both treatment. On the other hand, addition of garlic powder induce more prominent effects than clopidol in improving the feed conversion (at 21 day post infection) and serum creatinin level and decreasing the mortality rate. The results of the study were illustrated in the following tables.

Table 1: Effect of clopidol and garlic powder on oocyst count $\left(\times 10^{3}\right) / \mathrm{gm}$ feaces in Eimeria-infected broilers.

\begin{tabular}{cccc}
\hline $\begin{array}{c}\text { Groups / } \\
\text { Weeks P.I. }\end{array}$ & $\begin{array}{c}\text { Group (1) } \\
\text { Infected non treated }\end{array}$ & $\begin{array}{c}\text { Group (2) } \\
\text { Treated with clopidol }\end{array}$ & $\begin{array}{c}\text { Group (3) } \\
\text { Treated with garlic powder }\end{array}$ \\
\hline $1^{\text {st }}$ week & $1071.2 \pm 25.1 \mathrm{a}$ & $481.0 \pm 3.7 \mathrm{c}$ & $534.2 \pm 13.2 \mathrm{~b}$ \\
\hline $2^{\text {nd }}$ week & $582.0 \pm 7.82 \mathrm{a}$ & $141 . \pm 9.0 \mathrm{c}$ & $162.0 \pm 5.7 \mathrm{~b}$ \\
\hline $3^{\text {rd }}$ week & $271 \pm 0.314 \mathrm{a}$ & $161.8 \pm 1.32 \mathrm{~b}$ & $163.6 \pm 1.28 \mathrm{~b}$ \\
\hline
\end{tabular}

Means in the same row bearing different letters, differ significantly $(\mathrm{P}<0.05)$ 
Table 2: Lesion score in broiler chickens experimentally infected with Eimeria and Supplemented with clopidol and garlic powder.

\begin{tabular}{|c|c|}
\hline Groups & Lesion score \\
\hline $\begin{array}{l}\text { Group }(1) \\
\text { Infected non treated }\end{array}$ & +++ \\
\hline $\begin{array}{l}\text { Group }(2) \\
\text { Treated with clopidol }\end{array}$ & + \\
\hline $\begin{array}{l}\text { Group (3) } \\
\text { Treated with garlic powder }\end{array}$ & + \\
\hline
\end{tabular}

Table 3: Effect of clopidol and garlic powder on weekly body weight gain in chicken infected with Eimeria pp.

\begin{tabular}{cccc}
\hline $\begin{array}{c}\text { Groups / } \\
\text { Weeks P.I. }\end{array}$ & $\begin{array}{c}\text { Group (1) } \\
\text { Infected non treated }\end{array}$ & $\begin{array}{c}\text { Group (2) } \\
\text { Treated with clopidol }\end{array}$ & $\begin{array}{c}\text { Group (3) } \\
\text { Treated with garlic powder }\end{array}$ \\
\hline $1^{\text {st }}$ week & $183.5 \pm 6.9 \mathrm{a}$ & $319.31 \pm 8.0 \mathrm{c}$ & $285.7 \pm 6.3 \mathrm{~b}$ \\
\hline $2^{\text {nd }}$ week & $278.3 \pm 10.4 \mathrm{a}$ & $545.2 \pm 13.6 \mathrm{c}$ & $452.8 \pm 21.3 \mathrm{~b}$ \\
\hline $3^{\text {rd }}$ week & $296.2 \pm 4.6 \mathrm{a}$ & $472.3 \pm 13.6 \mathrm{~b}$ & $449.6 \pm 19.8 \mathrm{~b}$ \\
\hline
\end{tabular}

Means in the same row bearing different letters, differ significantly $(\mathrm{P}<0.05)$

Table 4: Effect of clopidol and garlic powder on weekly FCR in chicken.

Groups /

Weeks P.I.

Group (1)

Group (2)

Group (3)

Infected non treated Treated with clopidol

Treated with garlic powder

\begin{tabular}{cccc}
\hline $1^{\text {st }}$ week & $3.04 \pm 0.10 \mathrm{a}$ & $2.53 \pm 0.09 \mathrm{a}$ & $2.24 \pm 0.22 \mathrm{~b}$ \\
\hline $2^{\text {nd }}$ week & $3.07 \pm 0.12 \mathrm{a}$ & $2.46 \pm 0.09 \mathrm{~b}$ & $2.27 \pm 0.12 \mathrm{~b}$ \\
\hline $3^{\text {rd }}$ week & $3.45 \pm 0.15 \mathrm{a}$ & $3.05 \pm 0.18 \mathrm{~b}$ & $2.3 \pm 0.07 \mathrm{c}$
\end{tabular}

Means in the same row bearing different letters, differ significantly $(P<0.05)$

Table 5: Some biochemical analysis in broiler chickens experimentally infected with Eimeria spp. and Supplemented with clopidol or garlic powder.

\begin{tabular}{lcccc}
\multicolumn{1}{c}{ Groups } & AST (U/L) & ALT(U/L) & $\begin{array}{c}\text { Createnine } \\
(\mathbf{m g} / \mathbf{d L})\end{array}$ & uric acid (mg/dL) \\
\hline $\begin{array}{l}\text { Group (1) } \\
\text { Infected non treated }\end{array}$ & $97.2 \pm 6.1 \mathrm{a}$ & $22.1 \pm 2.0 \mathrm{a}$ & $0.84 \pm 0.047 \mathrm{a}$ & $9.38 \pm 0.34 \mathrm{a}$ \\
\hline $\begin{array}{l}\text { Group (2) } \\
\text { Infected treated with clopidol }\end{array}$ & $72.8 \pm 5.3 \mathrm{~b}$ & $14.3 \pm 0.88 \mathrm{~b}$ & $0.67 \pm 0.043 \mathrm{~b}$ & $6.25 \pm 0.23 \mathrm{~b}$ \\
\hline $\begin{array}{l}\text { Group (3) } \\
\text { Infected treated with } \\
\text { garlic powder }\end{array}$ & $74.6 \pm 5.9 \mathrm{~b}$ & $14.1 \pm 1.1 \mathrm{~b}$ & $0.51 \pm 0.058 \mathrm{c}$ & $6.22 \pm 0.26 \mathrm{~b}$ \\
\hline
\end{tabular}

Means in the same column bearing different letters, differ significantly $(P<0.05)$

Table 6: Effect of clopidol and garlic powder on mortality rate of infected chicks (30/group).

\begin{tabular}{cccc}
\hline $\begin{array}{c}\text { Groups / } \\
\text { Weeks P.I. }\end{array}$ & $\begin{array}{c}\text { Group (1) } \\
\text { Infected non treated }\end{array}$ & $\begin{array}{c}\text { Group (2) } \\
\text { Treated with clopidol }\end{array}$ & $\begin{array}{c}\text { Group (3) } \\
\text { Treated with garlic powder }\end{array}$ \\
\hline $1^{\text {st }}$ week & 4 & 3 & 2 \\
\hline $2^{\text {nd }}$ week & 2 & 1 & 1 \\
\hline $3^{\text {rd }}$ week & 0 & 0 & 0 \\
\hline Total \% & $20 \%$ & $13.3 \%$ & $10 \%$ \\
\hline
\end{tabular}




\section{DISCUSSION}

Shedding of Eimeria oocysts is an important parameter which used by researchers for evaluation of the anticoccidial drugs. The obtained data concerning the effect of clopidol and garlic powder on the oocysts count/gm dropping of chickens infected with Eimeria revealed that both clopidol and garlic powder evoked a significant decrease in oocyst count/gm droppings. The previous results agree with Ryley, (1967); Sevcik and Danek (1972); Ryley and Wilson, (1975), Singh et al. (1982) and Arakawa, (1991). The authors found that, the number of oocysts excreted in the faeces of clopidol treated birds was much lower than in the control non treated one. Moreover, Giebel et al. (1983) stated that clopidol was superior to nicarbazin in terms of deceasing the mortality, intestinal lesions and oocysts count. The anticoccidial effect of clopidol could be attributed to inhibition of the electron transport system within parasite mitochondria (Fry and Williams, 1984; Adam, 2001 and Walter, 2008).

Worku et al. (2009); Dkhil et al. (2011) and Pourali et al. (2014) reported that garlic significantly decreased oocysts output. Garlic is rich in organosulfur compounds whose precursors (allicin, diallyl sulfide and diallyl trisulfide) that believed to play key roles in antioxidant and anti-inflammatory effects. Therefore, garlic probably eliminated the negative effects of coccidial infection and improved the performance of infected birds (Banerjee et al., 2003). The same findings were reported also by khan et al. (2012).

The obtained findings in this work showed that adding of clopidol or garlic powder improved body weight gain and feed conversion of the infected birds. The biochemical analysis of the two groups treated with clopidol or garlic powder revealed improvement of liver \& kidney functions. Serum activity of AST, ALT, uric acid and creatinine were significantly decreased in treated groups in comparison with infected non treated one. The level of serum enzyme activity reflects the condition of liver, kidney, cecci and other organs. This could be due to the ability of coccidia to induce liver and kidney damage beside other factors such as loss of appetite, sloughing of mucosal cells in ceacum and bloody diarrhea. This result are in agreement with Kumor and Rawat (1975); Singh et al. (1976); El-Dahshan (1996); Ibrahim (1998) and Biu et al. (2006) and Pourali et al. (2014), who reported that chickens infected with coccidian developed hepatocelluler and renal damage, and that serum AST, ALT, uric acid and creatinine were significantly high. This adverse effect of coccidiosis could be explained on the base of increased the production of nitric oxide derived products (nitrite/nitrate) and malondialdehyde, lowered glutathione levels and decreased activities of catalase and superoxide dismutase, respectively. (Dkhil et al., 2011).

\section{CONCLUSION}

It could be concluded that, garlic powder $(5 \mathrm{gram} / \mathrm{kg}$ B.W) can be used as an alternative to traditional anticoccidial drugs as clopidol $(125 \mathrm{mg} / \mathrm{kg} \mathrm{B.W})$ to overcome coccidiosis in broiler.

\section{REFERENCES}

Abd El Rahman, M.S.; HILALy, M.S and Selim, M.K. (1982): Hand book of Diagnostic techniques of parasites of veterinay medicine, Cairo University, Fac. Vet. Med P. 34-36.

Adam, R.H. (2001): Veterinary Pharmacology and therapeutics. $8^{\text {th }}$ edition. Riviere, J. E. philadilpha: WB Sander company.

Arakawa, A.; Tanaka, Y.; Baba, E. and Fukata T. (1991): Effects of clopidol on sporulation and infectivity of Eimeria tenella oocysts. veterinary Parasitology, 38, (1): 55-60.

Bahadoran, S.; Hassanpour, H.; Khodad, P. and Shekarchian, S. (2013): Effect of clopidol and amprolium/ethopabate on performance and intestinal morphology of chickens with experimental coccidiosis. Kafkas Univ. Vet. Fak. Derg. 20 (4): 571-576.

Banerjee, SK.; Mukherjee, PK. and Maulik, SK. (2003): Garlic as an antioxidant: the good, the bad and the ugly. Phytother. Res., 17: 97-106.

Baraham, D. and Trinder, P. (1972): Enzymatic determination of uric acid. Analyst. 97: 142145.

Biu, A.A.; Yusuf, S.D. and Rabo. J.S. (2006): Use of Neem (Azadirachta indica) aqueous extract as a treatment for poultry coccidiosis in Borno State, Nigeria. African Scientist, 7,(3): 147-53.

Brander, G.; Pugh, D.; Byatar, R. and Jenkins, W. (1991): veterinary applied pharmacology and therapeutic. 5 th Ed., London, UK. P. 555-58.

Chowdhury, A.K.; Ahson, M.; Nazrul Islam, S.K. and Ahmed, Z.U. (1991): Efficacy of aqueous extract of garlic and allicin in experimental shigellosis in rabbits. Indian J. Med. Res. 93, 33-36.

Cox, F.E. (1998): Control of coccidiosis: Lessons from other sporozoa. Inter J. Parasitol, 28, 165-179, 1998.

Dalloul, R.A. and Lillehoj, H.S. (2005): Recent advances in immunomodulation and vaccination strategies against coccidiosis. Avian Dis., 49, 1-8.

Dkhil, M.A.; Abdel-Bakia, A.S.; Wunderlicha, D.F.; Siesa, E.H. and Al-Quraishya, S. (2011): Anticoccidial and antiinflammatory activity of garlic in murine Eimeria papillata infections. Veterinary Parasitology 175, 66-72.

Duraka, A.; Ozturk, H.S.; Olcay, E.; and Guven, C. (2002): Effects of garlic extract 
supplementation on blood lipid and antioxidant parameters and atherosclerotic plaque formation process in cholesterol-fed rabbits. J. Herbal Pharmacother. 2, 19-32.

Elbahy, N.M.; Mokhbattly A.M. and Verginia, M.E. (2006): Comparative clinicopathological studies on garlic ethanolic extract and halofuginone compound against coccidiosis in chicken. Kafr Elsheikh Vet. J., 1(1): 49-59.

El-Dahshan, H.A.M. (1996): Clinicopathological studies on the effect of some anticoccidial drugs in chickens. M.V.Sc. Thesis, Fac. Vet. Med. Suez canal University, Egypt.

Ernik, F. and Bedrnik, P. (2001): Controlling coccidiosis in broiler growing. Poult Inter, 40, 36-42.

Fleischauer, A.T.; Poole, C.H. and Arab, L. (2000): Garlic consumption and cancer prevention: meta-analyses of colorectal and stomach cancers. Am. J. Clin. Nutr. 72, 1047-1052.

Fry, M. and Williams, R.B. (1984): Effects of decoquinate and clopidol on electron transport in mitochondria of Eimeria tenella. Biochemical Pharmacology, 33(2): 229-240.

Ghazanfari, T.; Hassan, Z.M. and Khamesipour, A. (2006): Enhancement of peritoneal macrophage phagocytic activity against Leishmania major by garlic (Allium sativum) treatment. J. Ethnopharmacol. 103, 333-337.

Giebel, O.; Mazurkiewicz, M.; Mroz, A. and Wachink, Z. (1983): Resistance of field strain of Eimeria to the anticoccidial clopidol. Medycyna Veterinary Jna; 39(2): 82-85.

Ibrahim, IM. (1998): Effect of administration of halofuginone compound on blood cellular and biochemical parameters in poultry., Thesis for M.V.Sc. (clinical pathology), Fac. Vet. Med. Cairo University, Egypt.

Karasaki, Y.; Tsukamoto, S.; Mizusaki, K.; Sugiura, T. and Gotoh, S. (2001): A garlic lectin exerted an antitumor activity and induced apoptosis in human tumor cells. Food Res. Int. 34, 7-13.

Khan, RU.; Nikousefat, V.; Tufarelli, S.; Naz, S.; Javdani, M. and laudadio, M. (2012): Garlic (allium sativum) supplementation in poultry diets: effect on production and physiology. World Poult. Sci., 68: 417-424.

Kumor, H. and Rawat, J.S. (1975): A note on the effect of coccidiosis on serum enzyme and cholesterol in chicken. Indian J. anim. Sci. 45 (3)154-156.

Kumar, V.G.; Surendranathan, K.P.; Umesh, K.G.; Gayathri Devi, D.R. and Belwadi, M.R. (2003): Effect of onion (Allium cepa Linn.) and garlic (AlliumSativum Linn.) on plasma triglyceride content in Japanese quail.

(Coturnix coturnix japonicum). Indian J. Exp. Biol. 41, 88-90.
Long, P.L. (1993): Avian coccidiosis. In J.P. Krir, ed., Parasitic Protozoa, Vol. 4, $2^{\text {nd }}$ ed., pp. 188. San Diego: Academic Press.

Min, W.; Dalloul, R.A. and Lillehoj, H.S. (2004): Application of biotechnological tools for coccidian vaccine development. J. Vet. Sci., 5 (2004) 279-288.

Nok, A.J.; Williams, S. and Onyenekwe, P.C. (1996): Allium sativum-induced death of African trypanosomes. Parasitol. Res. 82, 634-637.

Peyghan, R.; Powell, M.D. and Zadkarami, M.R. (2008): In vitro effect of garlic extract and metronidazole against Neoparamoeba pemaquidensis, page1987 and isolated amoebae from Atlantic salmon. Pak. J. Biol. Sci. 11, 41-47.

Pourali, M.1; Kermanshahi, H.; Golian, A.; Razmi, G.R. and Soukhtanloo, M. (2014): Antioxidant and anticoccidial effects of garlic powder and sulfur amino acids on Eimeria-infected and uninfected broiler chickens. Iranian Journal of Veterinary Research, Shiraz University, 15, (3): 227-232.

Reitman, S. and Frankel, S. (1957): Colorimetric determination of GOT and GPT activity. Am. J. Clin. Path., 28: 56.

Ryley, J.F. and Wilson, R.G. (1975): Laboratory studies with some recent anticoccidials. Parasitology, 70, 203-222.

Ryley, J.F. (1967): Methyl benzoquate, a new widespectrum coccidiostat for chickens. The British Veterinary Journal, 123, 513-520.

Saif, A.S. (2003): Anticoccidial effects of metronidazole, Master thesis, Fac.Vet. Med., Tanta Univ.

SAS. (1998): SAS, procedure Guide. Version b 12 Ed. "SAS" Institute Inc., Cary, NC, USA.

Seeling, H.P. and Wust, H. (1969): Colorimetric method for determination of creatinine. Arztl. Lab., 15,34.

Sevcik, B. and Danek, J. (1972): Effect of clopidol on coccidiosis and subsequent immunity in chicks and pullets, in relation to dosage and interval between treatments. I. Repeated Infection. Veterinaria Spofa; 14(5/6): 269-278.

Singh, C.; Joshi, H. and Shoh, H. (1976): Biochemical studies in intestinal coccidiosis of poultry.; Pantnagar J.Res.,1(1): 63-66.

Singh, J.; Bajwa, R.S. and Gill, B.S. (1982): Effect of drugs against coccidial infection of chicken and the resultant immunity. Indian Journal of Parasitology, 6(2): 183-190.

Sundaram, S.G. and Milner, J.A. (1996): Diallyl disulfide inhibits the proliferation of human tumor cells in culture. Biochem. Biophys. Acta 1315, 15-20.

Wahba, A. (2003): Studies on the efficacy of garlic extract on cryptosporidiosis in experimentally infected mice. Egypt. J. Agric. Res. 81, 793803. 
Walter (2008): Handbookof Veterinary Pharmacology. 1st ed., State Avenue, Ames, Iowa, USA

Worku, M.; Franco, R. and Baldwin, K. (2009): Efficacy of garlic as an anthelmintic in adult boer goat. Arch. Biol. Sci., 61: 135-140.
Yoshida, H.; Iwata, N.; Katsuzaki, H.; Naganawa, R.; Ishikawa, K.; Fukuda, H.; Fujino, T. and Suzuki, A. (1998): Antimicrobial activity of a compound isolated from an oil-macerated garlic extract. Biosci. Biotechnol. Biochem. 62, 1014-1017.

\title{
دراسه تأثير الكليبيدول ومسحوق الثوم كمضاد للكوكسيديا على دجاج التسمين المصاب بالايميريا \\ محد فهمى الاكرورى ، جمال باز محمد باز ، رضا سمير فضلى
}

Email: dr_redafadly@yahoo.com_Assiut University web-site: www.aun.edu.eg

\begin{abstract}
المستهذف من هذه الدراسه البحث عن امكانيه إيجاد بدائل طبيعيه لمضادات الكوكسيديا التقليديه. في هذا البحث تمت مقارنه استخدام

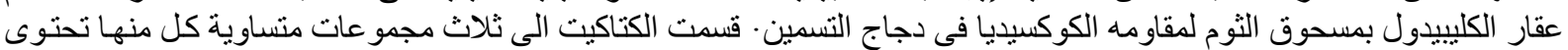

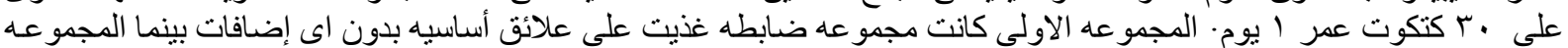

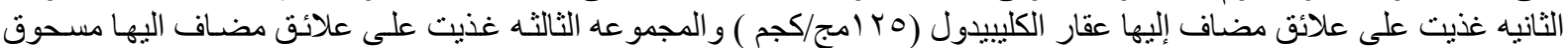

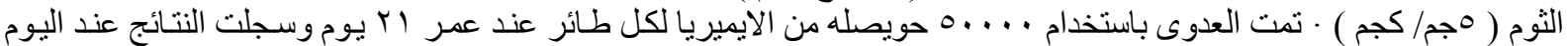

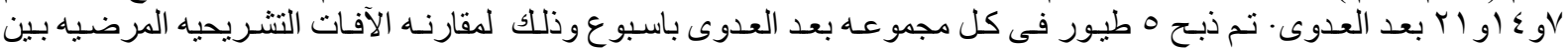

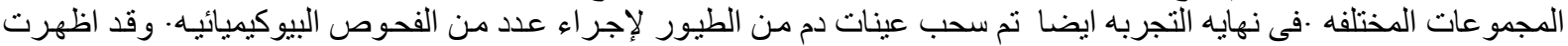

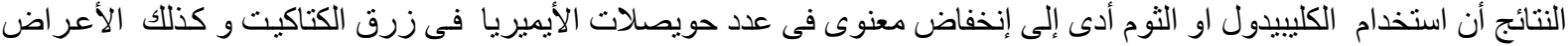

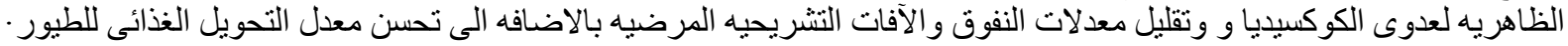

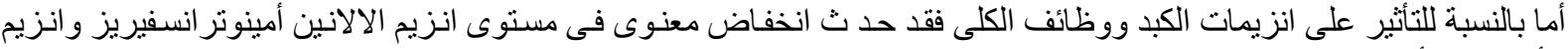

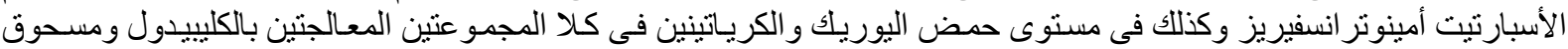

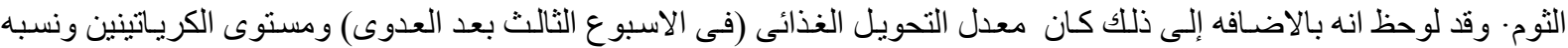

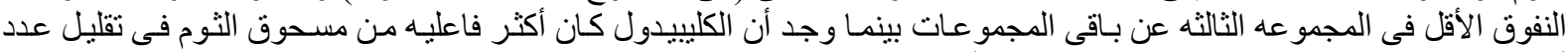
أكياس الايميريا فى زرق الكمرعاك الكتاكيت عند الاسبوع الأول و الثانى بعد العدوى.
\end{abstract}

